\title{
The MDGs, Empowerment and Accountability in Africa: Retrospect and Prospects
}

\author{
Adebayo Olukoshi
}

\begin{abstract}
Although the recognition in the historic Millennium Declaration of 2000 of the centrality of accountable governance to the quest for the advancement of the wellbeing of humankind was not translated into one of the MDGs when they were adopted in 2001, it could still have been legitimately expected that the implementation of the eight objectives that were agreed upon would bring important governance benefits in their own right, especially in the countries that were the main targets of the initiative, many of them in Africa. As it turned out however, the governance impacts of the MDGs have - for various reasons - left much to be desired. Correcting the governance discontents of the MDGs in the quest for a post-2015 global development agenda will require much closer and less donor-dominated attention to the strengthening of the local contexts, institutions, and actors of participation and accountability that are critical to securing and advancing democratic governance.
\end{abstract}

\section{Introduction}

As the countdown to 2015 gathers momentum, attention has been focused on the Millennium Development Goals (MDGs) and the prospects for the attainment of the key targets which were set under each of the eight specific objectives adopted by the United Nations General Assembly in 2001 following a set of proposals for action from the Secretary-General of the organisation that drew from the historic Millennium Declaration of 2000. From the outset, the MDGs attracted considerable interest on their potentialities - or insufficiency - in helping to overcome some of the enduring problems of poverty, exclusion and marginalisation that have for too long dogged the international development experience and marred the record of human progress. From governments, civil society groups and the private sector to donors, the academic community, and multilateral institutions, there was some expectation that the MDGs might, at last, offer a chance to humanity to begin to redress some of the most blatant experiences of suffering that have dented its record of civilisation (Sumner and Tiwari 2009; Manning 2009; Ganu and Oni 2011; Green et al. 2012).

The competition among states, multilateral agencies, sector ministries, and donors in the implementation of the MDGs, as well as the prospects for new forms of collaboration both among them and between them, civil society, and the private sector, helped sustain attention on goals, both globally and locally. ${ }^{1}$ The imminence of the 2015 date for attaining the objectives was to also generate a new sense of urgency on the efforts that need to be deployed for the achievement of the MDG targets.

The last few years have also seen the launching of campaigns and advocacy by different interest groups for what they feel a post-2015 global agenda for development might or should look like. ${ }^{2}$ The appointment by the UN SecretaryGeneral of a High-Level Panel to organise global consultations around a possible Post-2015 Development Agenda for the world was partly meant to respond to these campaigns. ${ }^{3}$ In so doing, effort has been invested in taking stock of the experience with, and lessons from, the implementation of the MDGs to date, pointing to some of the deficits in the MDGs, including their silences and discontents, and the ways in which these deficits could be redressed in any post-2015 agenda that the international community might adopt. ${ }^{4}$ 
One of the areas of discontent with the MDGs as adopted in 2001 is what some consider as its silence on governance, silence which is considered to be grave by those who work at the interface of governance and development (Ghaus-Pasha 2007; Manning 2009). ${ }^{5}$ It is to the governance dimensions of the MDGs that this essay addresses itself with particular attention to the dynamics of participation and accountability across Africa. The basic premise of the essay is that although the governance component of the Millennium Declaration may not have been explicitly incorporated into the MDGs, this has not necessarily meant a side-tracking of governance questions in the translation of the goals into policy. Indeed, important governance implications flow from the eight goals that were adopted which merit close attention in their own right. In this connection, it is suggested that although the proclamation of the MDGs may have enjoyed the support, both enthusiastic and reluctant, of a broad admixture of development actors across the African continent, insufficient attention was paid to the critical importance of the context of participation and accountability. For a variety of reasons, these were areas of weakness which meant that the pursuit of the goals did not adequately feed into and/or add to the improvement of democratic governance and, additionally, was frequently undermined by existing poor governance practices that have, historically, been a bane of equitable and sustained development in the African countries that were among the principal targets of the initiative.

\section{MDGs and their governance promises}

In spite of the legitimate disputes that raged as to whether they go far enough or even represent a faithful translation of what some consider as the radical Millennium Declaration into bold actionable objectives and targets ${ }^{6}{ }^{6}$ it would still be fair to suggest that the adoption of the MDGs marked an attempt by the international community to address some of the key challenges which have bedevilled the global development experience. In some ways, as a summation of global aspirations for promoting human progress, the MDGs could have been expected to be positively compatible with the demands of democratic governance, including participation and accountability across Africa. At one level, the key social objectives spoke to long-standing issues of livelihood and welfare that resonated with many. It was precisely because the MDGs, in spite of their limitations, covered social issues of concern that they engaged the attention of a broad coalition of non-state actors. Coming at a time when African countries were transiting from authoritarian rule to elected government under multi-party regimes, the MDGs were expected to play a role in ensuring that the dividends of democracy reached the generality of the working poor - helping, thereby, to consolidate the democratic transition that was under way (Ganu and Oni 2011; Thisday Newspaper 2010; AFRODAD 2005a).

At another level, in addressing a range of social issues for which local social movements have campaigned over a period of time, the MDGs as a globally adopted set of objectives fed into the long-standing quest in many countries where properly functioning social policy systems were not in place both for a prioritisation of social spending and the justiciability of core social and economic rights. Such rights are at the heart of the social bargain in being the citizens of a given political community. A range of social movements and civil society groups had made these rights the centrepiece of their campaigns for a fairer and more equitable world order. To the extent to which these rights are acknowledged in one form or another by the MDGs, then the goals themselves could be seen, as indeed some saw them, as being relevant to the search for a new social contract between state and society. Cast in terms of a minimum set of attainments and entitlements that should apply across the world and be in place by 2015, the MDGs also appeared to speak to the ideals of global solidarity and citizenship which ought to make for a bettergoverned international order (Ganu and Oni 2011; Moru 2005; AFRODAD 2005a).

\section{Furthermore, the distinct elements of} empowerment built into the MDGs appealed to a range of activist constituencies, especially those involved in the promotion of the rights of women and children, and the recognition of the critical relevance of civil society groups. Properly handled, these elements could be expected to contribute to the making of more active and engaged citizens, able to exercise their agency and choice in development and governance processes. The methodology adopted for the implementation of the goals provided for the monitoring of projects by civil society groups, and in so doing offered a potential chance for a greater engagement 
between state and society in the design and operationalisation of interventions. The national MDG strategies which countries were expected to elaborate were meant to facilitate such an engagement. The 'multi-stakeholder' approach adopted at the outset of the MDGs implied a readiness, on the face of things at least, to embrace a mutual accountability among key players. Mutual accountability at the national level was to be completed by shared and mutual accountability at the international level (UNDESA 2008; UN Millennium Project 2005).

The point should also not be forgotten that for Africa, much of Latin America and parts of Asia, the MDGs were adopted against the historical backdrop of at least two decades of sustained economic crisis which was exacerbated by the orthodox, deflationary, and austerity-based stabilisation and structural adjustment programmes favoured by the IMF and the World Bank in the name of a Washington Consensus. These programmes exacted a huge social cost, and pushed the working poor and marginalised groups deeper into poverty, vulnerability, and exclusion even as inequality grew. ${ }^{7}$ The highly limited attempts made by the World Bank and IMF to introduce social dimensions to mitigate the costs of their adjustment policies made very little difference, in part because they were halfhearted, poorly funded, and mainly served a public relations function, but also on account of the refusal of the Bretton Woods institutions to contemplate any thorough-going revision of their deflationary model. The chorus of domestic and international campaigns for economic reform policies that did not target the social expenditure of the state for wholesale retrenchment and, in so doing, reverse some of the key gains of postcolonial social policy, found some resonance in the MDGs as part of the millennial determination of the nations of the world to overcome social failings in the international development experience that are well within the means of humankind to overcome. It was a sufficient enough shift to elicit interest among campaigning groups to engage with the MDGs, states, the UN system and donors. ${ }^{8}$

From the point of view of many an activist, the international character of the MDGs seemed to offer an opportunity to better draw on the global commitments to which governments voluntarily adhered in order to more effectively push local social reform agendas around which they have been campaigning. ${ }^{9}$ Strategically, the MDGs were seen as potentially offering an opportunity to interface pressures for local participation and accountability with the expectation at the global level that governments would work towards meeting their commitments. The specific MDG monitoring and evaluation role accorded to civil society in the implementation process was seen as critical to securing both participation and accountability. Also, the measurement of local performance on the various MDGs and its translation into a comparative index of subregional, regional, and international performance offered potential new opportunities for dialogue between state and society on the social contract. ${ }^{10}$ The fact that the national MDG implementation strategies for meeting the agreed international targets were to be produced out of processes of multi-stakeholder engagement and agreement, was seen as beneficial to winning broad-based domestic ownership underpinned by the exercise of local policy choice.

\section{The MDGs and their governance discontents}

To embody a promise of strengthening participation and accountability, and empowering people whose exercise of citizenship has been abridged by poverty and want is one thing. To translate the promise into action is another. If the democratic governance-enhancing potentialities of the MDGs have generally failed to materialise, it is, in part, because the architecture for the attainment of the goals has favoured a vertical accountability to the global at the expense of the local, a by-product of the attempt to transmit internationally determined targets into the local arena mainly on the basis of support from the donor community. Countries across Africa, taking their cue from the incentives flowing from this architecture, and actively aided by agencies such as the UN Development Programme (UNDP), have invested heavily in pursuing implementation strategies aimed primarily at delivering routine 'credible' reports of performance to the international community, doing so by bean-counting if necessary. Within this parameter, the determination to 'deliver' on the MDGs has tended to override participation by and accountability to the citizens, including elected representatives performing oversight functions in parliament. Out of this has flowed a depoliticisation of development experience, and the reduction of participation and accountability 
to a series of procedural technicalities. Matters have, of course, not been helped by the enduring governance challenges in many African countries, including the fact that after over two decades of structural adjustment, they were still struggling with problems of policy space and ownership.

It would seem evident that the robustness of domestic national-level governance systems and processes was always going to be critical to the prospects for the attainment of the MDGs. One of the earliest governance challenges that emerged soon after the adoption of the MDGs centred on the modalities for the 'domestication' of the universal aspirations which they embodied. At one level, there was the immediate challenge of designing national strategies for implementation, including the costing of projects which could be undertaken with a view to meeting the MDG targets. For a majority of African countries, this task was carried out with active donor assistance and the technical superintendence of the UNDP which came to assume one of the most active roles in different countries as a central animator of the MDGs. Even civil society and parliamentary participation in local processes connected to the MDGs involved some degree of UNDP sponsorship and/or facilitation. ${ }^{11}$ At another level, the question of arrangements for financing the MDGs was immediately posed for many African countries and it was clear that the option that would prevail would carry some implications for local ownership and accountability. In the end, the financing of the MDGs became a principal donor domain managed either through existing channels of support and/or the cancellation of a proportion of bilateral and multilateral debts authorised on the understanding that the 'savings' made would be dedicated to the pursuit of the MDGs in the beneficiary countries. ${ }^{12}$

Furthermore, the quest for the 'domestication' of the MDGs broached upon the issue of institutional arrangements that were to be put in place for their pursuit. From an administrative-institutional point of view, were the MDGs to be carried out by the mainstream ministries of government or were they to be entrusted to a special MDG office or task force that could function outside of the regular bureaucracy? Across much of Africa, the popular preference was for one version or the other of the latter and governments created special MDG units/bureaus/focal points/task forces, sometimes strategically located in or associated with the offices of presidents or prime ministers, and occasionally, a Finance or Planning ministry. ${ }^{13}$ This approach was not entirely new as it had already been well practised with the institutional arrangements for tackling the HIV/AIDS pandemic, and the generalised agencification of government that was embraced as part of the reform of the public sector. ${ }^{14}$ It was, however, to carry some serious consequences.

For one, the interface between the line ministries and the special agencies and offices over mandate and role was not always obvious. For another, the connection between the national MDG strategy and existing or evolving national development plans and visions were mostly ambiguous. Where national development plans and visions had not already been elaborated, most countries had ongoing Poverty Reduction Strategy Papers (PRSPs) to which the national MDG strategies needed to be reconciled in dialogue with donors and institutions of the UN system. ${ }^{15}$ This approach to the administration of public affairs tends to weaken the mainstream institutions of government, including line ministries, which should ordinarily be responsible for the design and implementation of development programmes and interventions, whether special or not. ${ }^{16}$ The existing institutional arrangement, complete with its disciplines, did not therefore gain the fullness of the opportunity which the MDGs could have provided to strengthen internal aptitudes and proficiency or simply renew and update capacity. In the meantime, depending on the learning curve of the officials in the MDG agencies or focal point offices and special task forces, avoidable delays, errors, and mis-steps were registered as part of the launching of intervention programmes and initiatives (Thisday Nerespaper 2010). Ongoing mainstream ministerial initiatives even in domains that were directly relevant to the MDGs, though not necessarily carrying an MDG label, were not automatically built upon and the pursuit of synergies was hardly consistent or methodical. In consequence, in spite of the paucity of resources, efforts were sometimes needlessly duplicated.

Managing the sometimes huge resources which the MDG programmes generated from various donor sources also created concerns. The fact that a high proportion of MDG funds came from external donors meant that a considerable amount of energy and time was spent accounting 
to them on the management of the funds received. It also raised questions about the custody and/or approval for the disbursement of the resources between the special MDG offices and ministerial departments. Furthermore, tensions over procurement policy and the management of contract bidding were recorded between the MDG offices and agencies and the offices and agencies charged with government procurement and the enforcement of due process (ibid.). These tensions, in turn, produced project implementation and delivery delays that added to the costs of MDG initiatives (Thisday Newespaper 2010; CISLAC 2010). Perhaps inevitably, allegations of corruption and lack of accountability were often rife, even if evidence tended to be anecdotal. Community and civil society participation were also often abridged in the rush to register some progress after lengthy delays, with the consequence that complaints about marginalisation and lack of transparency tended to be commonplace. The absence of effective donor coordination did not help matters and the burden of donor reporting weighed heavily, and broadly to the detriment of accountability to societal stakeholders and citizens (AFRODAD 2005a, 2005b, 2006a, 2006b).

The attempt made in different parts of Africa to organise consultations and promote participation tended to be largely pro forma (IPU and UN Millennium Campaign 2010). The modalities that were commonly used included media briefings, workshops and seminars, the publication of calls for proposals for projects, briefing visits to local communities and traditional chiefly authorities, and public adverts and billboards on the MDGs. These modalities may have served some limited purposes but they hardly produced the kind of citizen mobilisation and participation which could allow the poor to exercise fuller agency in the determination of interventions. In the end, projects and programmes were initiated and implemented top-down in contexts and on issues where the needs to be served were enormous and the action called for needed to be nothing less than holistic and integrated. In spite of attempts by such agencies as UNDP to support the integration of the national MDG strategy into the policy mainstream, the impression persisted that the goals were essentially an 'external' affair underwritten by donors. This impression was further reinforced by the fact that parliaments felt themselves generally excluded from the MDGs. Where they got involved at all, it entailed fighting for a role and for voice (AllAfrica Parliamentary Conference on the MDGs 2012; IPU and UN Millennium Campaign 2010). African parliaments lacked access to research on the impact of the MDGs and the requisite finance to enable them to play an effective oversight role.

The governance limitations of the MDGs were connected to the broader issue of the most effective way to administer the development process with a view to achieving progressive structural transformation and delivering incremental improvements in citizen welfare and livelihood. The interconnections between the MDGs and other ongoing governmental initiatives were not properly established in part because they tended to be disconnected from domestic/local development planning and longterm visioning programmes whilst being fully integrated into global multilateral dynamics in the terrain of development. It was an irony that was clearly unintended but which was both predictable and avoidable. Locally, across Africa at least, many development actors and commentators were to voice reminders that the MDGs were neither a development plan nor a substitute for one, however laudable they may be. ${ }^{17}$ These reminders also broached upon the long-standing question of how the countries of Africa and the rest of the global South could evolve a macroeconomic framework that would be compatible with and enabling of the attainment of the broad aspirations of their peoples for significant social progress, especially given the unhappy legacy of neoliberal structural adjustment and the apparent lack of policy choice that appeared to stymie the process of democratisation (Mkandawire 1999). For the problems which the MDGs were meant to help tackle were, in part at least, the results and legacy of a maladjustment that flowed out of the pursuit of the Washington Consensus.

\section{Looking beyond 2015}

In seeking to redress the governance discontents, omissions and failings of the MDGs, especially with a view to a post-2015 agenda, it is important that the existing social policies of the countries of Africa and the broader development plans and long-term visions within which they are embedded are used as the principal building blocks and pillars around which global goals and targets are woven. Such an approach will not suffer from $e x$ 
post facto attempts at inventing local ownership and should curb the propensity for the needless, capacity-dissipating, and energy-sapping spawning of parallel bureaucratic structures for every major new (international) initiative. In fact, properly articulated and pursued, the approach will carry a possibility of strengthening institutional capacities for development implementation. It will also help to strengthen the institutional and social bases of democratisation in Africa. Global norms, standards and targets may have their place; their domestication cannot, however, be undertaken on the basis of a one-size-fits-all approach. The question of ensuring that macroeconomic policy is made to be compatible with broad social policy objectives, local visions of long-term social

\section{Notes}

1 The multiple and multi-layered dynamic of competition and collaboration among the different interests that coalesced locally and globally around the MDGs carried specific challenges of their own for the governance of the development process generally and the implementation of the MDGs more specifically.

2 These campaigns have been carried out as much with a view to securing - and strengthening - some of the existing MDG objectives as encouraging the adoption of new ones, and in some cases pushing for bolder targets, better/new methods of assessment of progress, increased local ownership of the goals, and opportunities for streamlining and mainstreaming the objectives into a broader and better institutionalised governance of the development process.

3 Concerns were expressed by some that a disproportionately early discussion of a post2015 agenda might actually detract from the pursuit of the goals and targets in the MDGs (see Sumner and Tiwari 2010). There is no evidence to suggest that this fear was justified - or even any serious danger that it was likely; the industry that has mushroomed around the MDGs locally and globally is a vast one, with considerable presence in the current global development architecture.

4 See for example, Moss (2010); Sumner and Tiwari (2009); Manning (2009); Green et al. (2012).

5 For many of those who regret this omission and have been campaigning for its recognition as a specific objective in the post-2015 period, progress, and the thirst for participatory democracies that yield dividends to the citizenry is a prerequisite for success in the achievement of targets for significantly improving and outrightly transforming livelihoods. It is, additionally, indispensable to the making of a new social contract between state and society without which the exercise of citizenship through active participation and mutual accountability will only be a formality, lacking in transformative politics. Perhaps, in engaging the theme of governance in its report, the High-Level Panel on a possible post-2015 agenda may have provided a window for a wholesale rethinking of the best ways for ensuring that the governance dimensions of global development objectives are structured to deliver transformative change in the lives of the poor.

reference is frequently made to the fact that the Millennium Declaration of 2000 was explicit about governance as a key area of interest. It is interesting that the report of the High-Level Panel on the post-2015 MDGs made clear references to the centrality of governance in the quest for the eradication of poverty and the promotion of human welfare.

6 See Clemens et al. (2007) for some of the concerns expressed. Easterly (2009) even suggests that the MDGs were structured in a way that set Africa up for failure, no matter what.

7 It is worth recalling here the influential public protest against the orthodox adjustment policies of the Bretton Woods Institutions and its pleas for an 'adjustment with a human face'.

8 See AFRODAD (2005a, 2005b, 2006a, 2006b); Igbuzor (2005).

9 See Manning (2009) for a much deeper reflection on this point.

10 All of this can be asserted without prejudice to the equally valid point which commentators such as Moss (2010) have made about the abuses and pitfalls of such global targets, indicators and measurements as those built into the MDGs and the attempts to operationalise them.

11 Thus it was that the UNDP supported Kenya, Nigeria, Ethiopia, Ghana, Lesotho, Swaziland and Liberia, to cite a few cases, in producing their national strategies and/or costing them. It was also responsible for promoting the parliamentary forum on MDGs in Uganda, and supported civil society to press for twiceyearly reports by the government to 
parliament on the status of the implementation of the MDGs in Kenya. 12 See AFRODAD (2005a, 2005b, 2006a, 2006b).

13 At one end of the spectrum, Nigeria, for example, the Office of the Senior Special Assistant to the President on the MDGs (SSAPMDGs) was created in 2005 with, among other things, budgetary and funding powers. In Ethiopia, an MDG Task Force was put in place chaired by the Finance Minister. In Kenya, a National MDGs Focal Point was designated and located in the Ministry of Planning.

14 The special, autonomous agencies, offices, focal points, and/or task forces established in several African countries to drive the implementation of the MDGs and the achievement of agreed targets were justified on the grounds that they allowed for focus and more efficient delivery. They were also meant to signal the high importance which governments attached to the MDGs. Furthermore, they were expected to offer a one-stop shop for resource mobilisation (from donors), enable a coordinated design and implementation of needed interventions, lead

\section{References}

AFRODAD (2006a) Linking the Poverty Reduction Strategy Paper and Millennium Development Goals: The Case of Ethiopia, Harare: African Forum and Network on Debt and Development

AFRODAD (2006b) Linking the Poverty Reduction Strategy Paper and Millennium Development Goals: The Case of Senegal, Harare: African Forum and Network on Debt and Development AFRODAD (2005a) The Politics of MDGs and Nigeria, Harare: African Forum and Network on Debt and Development

AFRODAD (2005b) Tanzania and the Millennium Development Goals: A Critical Appraisal of the Global Partnership for Development (Goal 8), Harare: African Forum and Network on Debt and Development Akosile, Abimbola (2010) 'Provide Structures for People's Participation in MDGs', Thisday Newspaper (Lagos and Abuja), 15 December All-Africa Parliamentary Conference on the MDGs (2012) 'Accountability for Achieving the MDGs: The Role of Parliament', mimeo, Addis Ababa AUC/ECA/AfDB/UNDP (2013) MDG Report 2013: Assessing Progress in Africa Toward the Millennium Development Goals, New York: United Nations Development Programme (UNDP)

CISLAC (Civil Society and Legislative Advocacy Centre) (2010) 'Communiqué Issued at the the interface with relevant ministerial departments, undertake the mobilisation of civil society and community input and participation, and serve as the main site for organisation of accountability, both to donors and to the multilateral system.

15 Ethiopia was one of the countries that was resolute in merging its PRSP and national MDGs strategy into one programme (see AFRODAD 2006a) but in several other instances such as the Gambia, Gabon and Guinea, this was not the approach that was adopted.

16 South Africa was one country which did not create any special agency or office for the MDGs as such but even there, there was some initial 'confusion' over the focal point institution for coordinating reporting. The Department for International Relations initially took on that role but the report it produced was much contested by civil society which generated a shadow report of its own. Statistics South Africa subsequently took responsibility for producing the report.

17 See AFRODAD (2006b) for example.

End of a Capacity-Building Workshop for CSOs and CBOs on Budget Tracking on MDG Allocations', mimeo, Kano

Clemens, M.; Kenny, C. and Moss, T. (2007) 'The Trouble with the MDGs: Confronting Expectations of Aid and Development Success', World Development 35.5: 735-51

Easterly, William (2009) 'How the Millennium Development Goals are Unfair to Africa', World Development 37.1: 26-35

Ganu, Josephine and Oni, Michael Abiodun (eds) (2011) MDGs as Instruments for Development in Africa, Singapore: Babcock and Valley View Universities/National Library of Singapore and Arabian Group of Journals

Ghaus-Pasha, Aisha (2007) 'Governance for the Millennium Development Goals: Core Issues and Good Practices', mimeo, United Nations Department of Economic and Social Affairs (UNDESA)

Green, Duncan; Hale, Stephen and Lockwood, Matthew (2012) How Can a Post-2015 Agenda

Drive Real Change?: The Political Economy of Global Commitments, Oxfam Discussion Paper, October

Igbuzor, Otive (2006) 'The Millennium

Development Goals: Can Nigeria Meet the Goals in 2015?', mimeo, Abuja 
Igbuzor, Otive (2005) 'Review of the Nigerian Millennium Development Goals 2005 Report', in John Moru (ed.), Another Nigeria is Possible: Proceedings of the First Nigeria Social Forum, Abuja: Nigeria Social Forum

IPU and the UN Millennium Campaign (2010) Analytical Study of Parliamentary Mechanisms for the MDGs, New York: Inter-Parliamentary Union and UN Millennium Campaign Manning, Richard (2009) Using Indicators to Encourage Development: Lessons from the Millennium Development Goals, DIIS Report Working Paper 01, Copenhagen: Danish Institute for International Studies Mkandawire, Thandika (1999) 'Crisis Management and the Making of "Choiceless Democracies" in Africa', in Richard Joseph (ed.), The State, Conflict and Democracy in Africa, Boulder CO: Lynne Rienner

Moru, John (ed.) (2005) Another Nigeria is Possible: Proceedings of the First Nigeria Social Forum, Abuja: Nigeria Social Forum
Moss, Todd (2010) 'What Next for the Millennium Development Goals?', Global Policy 1.2: 218-20 Sumner, Andy and Tiwari, Meera (2010) Global Poverty Reduction to 2015 and Beyond: What has been the Impact of the MDGs and What are the Options for a Post-2015 Framework?, IDS Working Paper 348, Brighton: IDS

Sumner, Andy and Tiwari, Meera (2009) After 2015: International Development Policy at a Crossroads, London: Palgrave Macmillan Thisday Newspaper (2010) 'MDGs Quick Win as Campaign Tools for 2011 Elections', Abuja, 11 July

UN Millennium Project (2005) Investing in Development: A Practical Plan to Achieve the Millennium Development Goals - An Overview, New York: United Nations Development Programme (UNDP)

UNDESA (2008) Participatory Governance and the Millennium Development Goals (MDGs), New York: UN Department of Economic and Social Affairs 